\title{
Perbandingan Masalah Mental Emosional dan Karakteristik Pasien Remaja dengan Talasemia Mayor di Poli Talasemia RSUP Dr. Hasan Sadikin Bandung
}

Qory Aulia Sukma, ${ }^{1}$ Rodman Tarigan, ${ }^{2}$ Lynna Lidyana ${ }^{3}$

${ }^{1}$ Fakultas Kedokteran, ${ }^{2}$ Departemen Ilmu Kesehatan Anak, ${ }^{3}$ Departemen Ilmu Kesehatan Jiwa Fakultas Kedokteran Universitas Padjadjaran - Rumah Sakit Dr. Hasan Sadikin, Bandung

Latar belakang. Talasemia adalah penyakit genetik hematologik yang berdampak terhadap perubahan fisik dan kegiatan sehari-hari pasien sehingga berpengaruh pada psikososial pasien, terutama pasien remaja yang mengalami perubahan emosional pada fase transisi menuju dewasa. Tujuan. Penelitian dilakukan untuk mengetahui perbandingan masalah mental emosional dengan karakteristik pasien remaja talasemia mayor di Poli Talasemia RSUP Dr. Hasan Sadikin Bandung.

Metode. Penelitian ini adalah studi deskriptif-analitik dengan desain potong lintang yang dilakukan pada bulan Agustus- September 2019. Subjek penelitian adalah 96 pasien talasemia di Poli Talasemia RSUP Dr. Hasan Sadikin Bandung dengan kelompok usia 11-17 tahun yang mengisi self-assessment Strengths and Difficulties Questionnaire (SDQ).

Hasil. Dari 96 subjek penelitian, 49(51\%) adalah perempuan. Enam puluh empat (67\%) adalah kelompok usia 11-14 tahun, dan 46(48\%) di antaranya adalah siswa SMP. Gambaran masalah mental emosional pasien meliputi masalah emosional 17(18\%), conduct 12(12\%), hiperaktivitas $8(8 \%)$, dan masalah hubungan dengan teman sebaya $7(7 \%)$.

Kesimpulan. Tidak ada perbedaan antara masalah mental emosional dan karakteristik pasien remaja dengan talasemia mayor. Sari Pediatri 2021;23(1):23-7

Kata kunci: talasemia, mental emosional, remaja

\section{Relation between Mental Emotional Problems and Characteristics of Adolescent Patients with Thalassemia Major in Poli Talasemia RSUP Dr. Hasan Sadikin Bandung}

Qory Aulia Sukma, ${ }^{1}$ Rodman Tarigan, ${ }^{2}$ Lynna Lidyana ${ }^{3}$

Background. Thalassemia is a hematologic genetic disease that has the impact of physical changes and disturbances to the daily activities of patients. It affects the psychosocial of patients, especially adolescent patients who are in a phase of transition to adulthood and experiencing emotional changes.

Objective. This research is conducted to find out comparison between mental emotional and characteristics of adolescent patients with thalassemia major in Poli Thalassemia RSUP Dr. Hasan Sadikin Bandung.

Methods. This research is a descriptive-analytic cross-sectional study conducted in August-September 2019. The research subjects were 96 thalassemia patients in the Poli Thalassemia RSUP Hasan Sadikin Bandung with an age group of 11-17 years who filled out the self-assessment Strengths and Difficulties Questionnaire (SDQ).

Result. Of 96 research subjects, 49 people (51\%) were women, 64 people (67\%) were the 11-14 years age group, and 46 people (48\%) were junior high school students. Mental-emotional problems of patients included emotional problems of 17 people (18\%), conduct problems of 12 people (12\%), hyperactivity of 8 people $(8 \%)$, and peer problems of 7 people $(7 \%)$.

Conclusion. There is no difference between mental-emotional and characteristics of an adolescent patients with thalassemia major.Sari Pediatri 2021;23(1):23-7

Keywords: thalassemia, mental emotional, adolescent

Alamat korespondensi: Qory Aulia Sukma. Departemen Ilmu Kesehatan Anak Fakultas Kedokteran Unpad, RS Hasan Sadikin, Jalan Pasteur No. 38, Bandung, 40161, Jawa Barat.Email: qory16001@mail.unpad.ac.id 
Qory Aulia Sukma dkk: Perbandingan masalah mental emosional dan karakteristik pasien remaja dengan talasemia mayor

$\mathrm{T}$ alasemia adalah penyakit genetik hematologik yang mengakibatkan adanya defek sintesis satu atau lebih rantai globin. Ketidakseimbangan rantai globin menyebabkan hemolisis sehingga jumlah hemoglobin yang berfungsi dalam pengangkutan oksigen sel darah merah ke seluruh bagian tubuh menjadi terganggu. ${ }^{1,2}$

Di Indonesia, kasus talasemia cukup tinggi karena setiap tahun akan lahir sekitar 3000 bayi yang berpotensi talasemia. ${ }^{3}$ Provinsi Jawa Barat sampai dengan tahun 2013 menjadi daerah dengan prevalensi talasemia terbanyak di Indonesia, (42\%) dari total 6647 orang. ${ }^{4}$ Di Rumah Sakit Hasan Sadikin, Bandung, data Instalasi Rekam Medis Rawat Jalan menunjukkan bahwa dalam rentang waktu 1 Januari 2018 - 28 Februari 2019, terdapat 3280 pasien Talasemia yang berusia 11-16 tahun.

Penyakit talasemia dapat menimbulkan berbagai perubahan fisik pada penderitanya. Perubahan fisik yang dialami, seperti keterlambatan pertumbuhan, postur tubuh pendek, wajah spesifik talasemia (facies colley) serta pembesaran hati dan limpa (spleenomegali) yang menyebabkan perut tampak menonjol. Penderita talasemia juga mengalami hambatan di sekolah karena sering dirawat di rumah sakit dan daya konsentrasi yang rendah menyebabkan prestasi sekolah di bawah rata-rata. Perubahan dan kelemahan fisik yang dimiliki tersebut berdampak secara psikososial, yaitu rendah diri, malu, dan tidak berdaya. ${ }^{5}$ Di India, sebuah penelitian menunjukkan bahwa $74 \%$ pasien talasemia memiliki kualitas hidup yang buruk. Salah satunya adalah masalah psikologis yang meliputi gejala cemas, depresi, dan gangguan perilaku yang dialami $44 \%$ pasien. ${ }^{6}$ Penelitian di Iran mendapatkan bahwa $50,8 \%$ dari pasien talasemia mayor memiliki gangguan kesehatan mental. ${ }^{7}$

Saat ini di Bandung, Jawa Barat, belum ada penelitian yang menunjukan hubungan antara masalah mental emosional yang dimiliki oleh pasien remaja dengan talasemia mayor terhadap karakteristik yang dimiliki. Instrumen yang digunakan adalah kuesioner kekuatan dan kesulitan (SDQ) yang memiliki lima subskala. Subskala kekuatan meliputi perilaku prososial, sedangkan subskala kesulitan meliputi masalah emosional, masalah tingkah laku, hiperaktivitas dan masalah hubungan dengan teman sebaya.

Penelitian ini bertujuan untuk mengetahui perbandingan masalah mental emosional dan karakteristik yang dimiliki pasien remaja dengan talasemia mayor di Poli Talasemia RSUP Dr. Hasan
Sadikin Bandung selama periode 6 Agustus - 6 September 2019 sehingga dapat memberikan gambaran bentuk intervensi yang dapat dilakukan terhadap masalah mental emosional pada pasien dengan talasemia mayor. Selain itu, diharapkan data dari penelitian ini dapat menjadi bahan untuk dikembangkan ke penelitian selanjutnya dan perkembangan ilmu pengetahuan.

\section{Metode}

Penelitian ini adalah studi analitik dengan desain potong lintang yang dilakukan pada 6 Agustus 2019 6 September 2019 di Poli Talasemia RSUP Dr. Hasan Sadikin, Bandung. Subjek penelitian merupakan pasien remaja dengan talasemia mayor pada kelompok usia 11-17 tahun. Jumlah sampel penelitian ditentukan menggunakan formula deskriptif kategorik yang kemudian didapatkan jumlah minimum sampel 96. Kriteria inklusi penelitian adalah pasien talasemia mayor berusia 11-17 tahun yang bersedia mengikuti penelitian dengan menandatangani lembar informed consent. Untuk kriteria eksklusi penelitian adalah pasien yang tidak dapat membaca (buta huruf), pasien yang tidak bersedia melanjutkan penelitian, dan data kuesioner yang tidak dijawab dengan lengkap oleh pasien.

Penelitian ini dilakukan dengan telah mendapatkan izin dari Komite Etik Penelitian Universitas Padjadjaran serta izin penelitian dari Bagian Pendidikan dan Penelitian (DIKLIT) RSUP Dr. Hasan Sadikin Bandung. Penelitian dilakukan dengan mengumpulkan data dari hasil kuesioner kekuatan dan kesulitan (SDQ) yang diisi langsung oleh pasien. Kuesioner ini terdiri dari 25 poin pernyataan yang dibagi dalam 5 subskala, yaitu masalah emosional, tingkah laku, hiperaktivitas, dan masalah hubungan dengan teman sebaya, serta perilaku prososial. Setiap pernyataan dijawab dengan tidak benar, agak benar, dan benar. Skor dari pernyataan akan dijumlahkan dan dapat dikategorikan menjadi normal, borderline, dan abnormal.

Penelitian ini menitikberatkan pada gambaran hasil abnormal pada masalah mental emosional yang dinilai dari empat subskala yang ada, yaitu masalah emosional, tingkah laku, hiperaktivitas, dan masalah hubungan dengan teman sebaya sehingga tidak dilakukan analisis subskala perilaku prososial. Hasil skoring juga dilakukan analisis dengan melakukan perbandingan terhadap karakteristik dari pasien. Data kemudian diolah dengan 
IBM SPSS 26.0 dengan uji statistik Mann-Whitney dan Kruskal-Wallis, lalu disajikan dalam bentuk tabel karakteristik pasien, sebaran masalah mental emosional berdasarkan hasil SDQ, serta perbandingan hasil skoring dengan karakteristik pasien.

\section{Hasil}

Penelitian ini melibatkan 96 responden dari total populasi yang merupakan pasien remaja dengan diagnosis talasemia mayor. Seluruh data yang didapatkan berjumlah 96 yang sesuai dengan kriteria inklusi dari penelitian.

Tabel 1. Karakteristik pasien berdasarkan demografis

\begin{tabular}{lcc}
\hline Karakteristik & Jumlah & $\%$ \\
\hline Jenis kelamin & & \\
$\quad$ Laki-laki & 47 & 49 \\
$\quad$ Perempuan & 49 & 51 \\
Usia (tahun) & & \\
$\quad 11-14$ & 64 & 67 \\
$15-17$ & 32 & 33 \\
Tingkat pendidikan & & \\
SD & 27 & 28 \\
SMP & 46 & 48 \\
SMA & 23 & 24 \\
\hline
\end{tabular}

Tabel 2. Karakteristik pasien berdasarkan hasil kuesioner SDQ

\begin{tabular}{|c|c|c|c|}
\hline Subskala & $\begin{array}{l}\text { Normal } \\
(\%)\end{array}$ & $\begin{array}{c}\text { Borderline } \\
(\%)\end{array}$ & $\begin{array}{c}\text { Abnormal } \\
(\%)\end{array}$ \\
\hline Masalah emosi & $69(72)$ & $10(10)$ & $17(18)$ \\
\hline Masalah conduct & $70(73)$ & $14(15)$ & $12(12)$ \\
\hline Hiperaktivitas & $83(87)$ & $5(5)$ & $8(8)$ \\
\hline $\begin{array}{l}\text { Masalah hubungan } \\
\text { dengan teman sebaya }\end{array}$ & $70(73)$ & $19(20)$ & $7(7)$ \\
\hline Total kesulitan & $68(71)$ & $16(17)$ & $12(12)$ \\
\hline
\end{tabular}

Berdasarkan data pada Tabel 1, didapatkan proporsi terbanyak untuk karakteristik jenis kelamin adalah perempuan (51\%). Proporsi terbanyak untuk karakteristik usia pasien adalah 11-14 tahun (67\%) yang merupakan fase remaja awal. Pada umumnya, pasien memiliki tingkat pendidikan pada jenjang SMP (48\%).

Berdasarkan data pada Tabel 2, proporsi masalah mental emosional pasien terbanyak adalah masalah emosi sebanyak 17 (18\%) dan masalah conduct 12 (12\%). Proporsi untuk masalah mental emosional lainnya, yaitu hiperaktivitas $8(8 \%)$ dan masalah hubungan dengan teman sebaya 7 (7\%) anak. Masalah mental emosional pasien secara keseluruhan jika dinilai dari total subskala kesulitan memiliki proporsi 12 (12\%) anak.

Tabel 3. Perbandingan karakteristik jenis kelamin pasien dengan skor subskala kesulitan SDQ

\begin{tabular}{|c|c|c|c|}
\hline \multirow[b]{2}{*}{ Subskala } & \multicolumn{2}{|c|}{ Median skor (range) } & \multirow[b]{2}{*}{$\mathrm{p}$} \\
\hline & $\begin{array}{l}\text { Laki-Laki } \\
(\mathrm{n}=47)\end{array}$ & $\begin{array}{l}\text { Perempuan } \\
\quad(\mathrm{n}=49)\end{array}$ & \\
\hline Masalah emosional & $3(0-10)$ & $4(0-10)$ & 0,099 \\
\hline Masalah conduct & $2(0-7)$ & $2(0-6)$ & 0,868 \\
\hline Hiperaktivitas & $3(0-7)$ & $4(0-8)$ & 0,882 \\
\hline $\begin{array}{l}\text { Masalah hubungan } \\
\text { dengan teman sebaya }\end{array}$ & $2(0-8)$ & $2(0-8)$ & 0,929 \\
\hline
\end{tabular}

Tabel 4. Perbandingan karakteristik usia pasien dengan skor subskala kesulitan SDQ

\begin{tabular}{lccc}
\hline \multirow{2}{*}{ Subskala } & \multicolumn{2}{c}{ Median skor (range) } & \\
\cline { 2 - 3 } & $\begin{array}{c}11-14 \\
(\mathrm{n}=64)\end{array}$ & $\begin{array}{c}15-17 \\
(\mathrm{n}=32)\end{array}$ & $\mathrm{p}$ \\
\hline Masalah emosional & $4(0-10)$ & $4(0-9)$ & 0,374 \\
Masalah conduct & $2(0-7)$ & $3(0-6)$ & 0,077 \\
Hiperaktivitas & $3(0-8)$ & $3(0-8)$ & 0,462 \\
$\begin{array}{l}\text { Masalah hubungan } \\
\text { dengan teman sebaya }\end{array}$ & $2(0-8)$ & $2(0-8)$ & 0,320 \\
\hline $\begin{array}{l}\mathrm{p}>0,05=\text { tidak ada perbedaan bermakna } \\
\end{array}$ & &
\end{tabular}

Tabel 5. Perbandingan karakteristik tingkat pendidikan pasien dengan skor subskala kesulitan SDQ

\begin{tabular}{|c|c|c|c|c|}
\hline \multirow[b]{2}{*}{ Subskala } & \multicolumn{3}{|c|}{ Median skor (range) } & \multirow[b]{2}{*}{$\mathrm{p}$} \\
\hline & $\begin{array}{c}\mathrm{SD} \\
(\mathrm{n}=27)\end{array}$ & $\begin{array}{c}\text { SMP } \\
(\mathrm{n}=46)\end{array}$ & $\begin{array}{c}\text { SMA } \\
(\mathrm{n}=23)\end{array}$ & \\
\hline Masalah emosional & $4(0-10)$ & $4(0-9)$ & $4(0-9)$ & 0,495 \\
\hline Masalah conduct & $2(0-7)$ & $2(0-6)$ & $3(1-5)$ & 0,592 \\
\hline Hiperaktivitas & $4(0-8)$ & $3(0-8)$ & $3(0-6)$ & 0,252 \\
\hline $\begin{array}{l}\text { Masalah hubungan } \\
\text { dengan teman } \\
\text { sebaya }\end{array}$ & $2(0-8)$ & $2(0-8)$ & $2(0-7)$ & 0,860 \\
\hline
\end{tabular}

Tabel 3 menunjukkan perbandingan skor subskala kesulitan dengan karakteristik jenis kelamin pasien, sementara Tabel 4 merupakan perbandingan dengan karakteristik usia pasien. Kedua perbandingan diuji dengan menggunakan Mann-Whitney. Tabel 5 
merupakan perbandingan dengan karakteristik tingkat pendidikan pasien melalui uji Kruskal-Wallis. Perbandingan skor terhadap setiap subskala kesulitan untuk seluruh karakteristik memiliki nilai $\mathrm{p}>0,05$.

\section{Pembahasan}

Pada penelitian ini didapatkan bahwa jenis kelamin pasien talasemia hampir sama besar pada perempuan dan laki-laki. Hasil tersebut sesuai dengan hasil penelitian sebelumnya di RSUP Dr. Hasan Sadikin Bandung, yaitu jumlah pasien talasemia perempuan 51\% dan laki-laki 49\%. ${ }^{9}$ Hal ini diduga karena talasemia merupakan penyakit yang diturunkan melalui gen autosomal sehingga risiko dialami oleh perempuan dan laki-laki sama besarnya. ${ }^{10}$

Dari seluruh subjek penelitian, kelompok usia terbanyak adalah pasien dengan kelompok usia 1114 tahun. Kelompok usia ini dapat dikategorikan sebagai remaja awal. Remaja awal merupakan fase anak terpapar perubahan mental awal menuju dewasa. Krisis identitas, kesadaran pentingnya teman dekat, kadang-kadang berlaku kasar, dan lainnya merupakan karakteristik perubahan tersebut. ${ }^{11}$ Hasil penelitian juga menunjukkan bahwa perubahan mental tersebut paling banyak dialami oleh siswa Sekolah Menengah Pertama (SMP) kemudian diikuti oleh siswa Sekolah Menengah Atas (SMA). Hal ini dapat menjadi faktor risiko terhadap gangguan mental emosional pada pasien talasemia karena penelitian yang dilakukan oleh Mubasyiroh $\mathrm{dkk}^{12}$ menunjukkan bahwa gangguan mental emosional terjadi sebesar $60,17 \%$ pada pelajar SMP-SMA.

Masalah emosional adalah masalah dengan proporsi paling banyak pada pasien talasemia (18\%). Proporsi ini sedikit lebih tinggi dibandingkan masalah emosional pada penelitian Behdani dkk. ${ }^{13}$ Masalah emosional pada penelitian tersebut memiliki proporsi $16,7 \%$. $\mathrm{Hal}$ ini dapat disebabkan oleh penyakit talasemia yang mereka derita merupakan penyakit yang membutuhkan pengobatan seumur hidup sehingga dapat memunculkan masalah psikososial pada pasien. Usia remaja yang rentan perubahan emosional juga dapat menjadi faktor pendukung masalah emosional tersebut. ${ }^{9,14}$

Masalah kedua yang paling banyak dialami oleh pasien adalah masalah conduct dengan proporsi $12 \%$. Jumlah ini hampir sama dengan proporsi pada penelitian Behdani $\mathrm{dkk}^{13}$ yang menunjukkan proporsi masalah conduct $11,9 \%$. Hal ini dapat diakibatkan pengobatan tranfusi darah yang dilakukan secara rutin. Transfusi darah berdampak kepada kehidupan keseharian mereka karena rutinitas ke rumah sakit untuk melakukan transfusi tersebut. ${ }^{15}$ Pada kegiatan sekolah pasien, rutinitas ke rumah sakit akan menyebabkan absensi sekolah meningkat. Hal tersebut dapat memberikan tekanan emosional terhadap pasien yang bisa menyebabkan masalah tingkah laku atau gangguan perilaku eksternal seperti lebih agresif. ${ }^{16}$

Data penelitian untuk hasil kuesioner SDQ menunjukkan bahwa proporsi masalah mental emosional berdasarkan total skor subskala kesulitan yang dimiliki oleh pasien adalah $12 \%$. Penemuan ini berbeda dengan hasil penelitian Behdani $\mathrm{dkk}^{13}$ yang mendapatkan proporsi lebih terhadap masalah mental emosional, yaitu $26,2 \%$. Perbedaan ini dapat dikarenakan pemahaman pasien sudah baik dalam menerima penyakit talasemia sehingga dapat mengendalikan diri terhadap perubahan mental emosional yang mereka rasakan. Penelitian sebelumnya pada pasien talasemia di RSUP Dr. Hasan Sadikin Bandung, Maghfiroh $\mathrm{dkk}^{17}$ menunjukkan bahwa pasien talasemia memiliki penilaian harga diri yang tinggi terhadap perasaan diterima dan perasaan berharga dari penyakit talasemia yang dialami.

Dari hasil uji perbandingan untuk karakteristik pasien dengan skor subskala kesulitan (SDQ), baik untuk karakteristik jenis kelamin, usia, maupun tingkat pendidikan tidak didapatkan adanya perbedaan untuk seluruh karakteristik pasien. Pengujian penelitian ini belum terlalu spesifik terhadap penyakit talasemia. Karakteristik terkait penyakit talasemia yang mungkin menjadi faktor pengaruh masalah mental emosional pasien talasemia belum diuji. Hal ini dapat menjadi data untuk dikembangkan dalam penelitian lebih lanjut.

Keterbatasan dalam penelitian ini adalah waktu penelitian yang terbatas sehingga jumlah subjek penelitian terlalu sedikit dibandingkan populasi dari pasien remaja dengan talasemia mayor yang ada di RSUP Dr. Hasan Sadikin Bandung. Penelitian ini belum dapat menggambarkan secara keseluruhan masalah mental emosional pasien remaja dengan talasemia mayor di RSUP Dr. Hasan Sadikin Bandung. Penelitian selanjutnya diharapkan dapat memiliki durasi yang lebih panjang sehingga subjek penelitian yang diambil juga dapat lebih banyak agar bisa digunakan sebagai data yang representatif. 
Saran untuk penelitian ini adalah pemeriksaan yang lebih lanjut terhadap pasien yang memiliki masalah mental emosional oleh tenaga kesehatan yang ahli di bidangnya agar dapat diberikan intervensi yang tepat jika memang pasien memiliki gangguan kesehatan mental. Hal ini dikarenakan SDQ merupakan alat skrining masalah mental emosional, tetapi belum dapat dijadikan alat untuk diagnosis gangguan kesehatan mental. Penelitian ini juga diharapkan dapat meningkatkan kesadaran orang tua dan masyarakat di sekitar pasien talasemia mayor untuk memberikan pendampingan dan support kepada pasien dalam menjalani kehidupannya.

\section{Kesimpulan}

Pada penelitian yang dilakukan, peneliti berhasil mendapatkan data mengenai karakteristik pasien dan gambaran masalah mental emosional pasien remaja dengan talasemia mayor di poli talasemia RSUP Dr. Hasan Sadikin Bandung. Dari kedua data ditemukan tidak ada perbedaan antara karakteristik pasien dengan setiap skor subskala kesulitan (SDQ)/masalah mental emosional pasien talasemia mayor.

\section{Daftar pustaka}

1. Dimas P, Chris T, Hikari AS. Talasemia. Dalam: Chris Tanto, Frans Liwang, Sonia Hanifati, Eka Adip Pradipta, penyunting.. Edisi keempat, jilid kedua. Jakarta: Kapita Selekta Kedokteran; 2016.h.59.

2. Safitri R, Ernawaty J, Karim D. Hubungan kepatuhan tranfusi dan konsumsi kelasi besi terhadap pertumbuhan anak dengan talasemia. JOM 2015;2:1474-83.

3. Ghozali M, Dalimoenthe NZ. Skrining thalassemia beta minor pada siswa SMA di Jatinangor. Jurnal Sistem Kesehatan 2016 ;1:133-8.
4. Mulyani M, Fahrudin A. Reaksi psikososial terhadap penyakit di kalangan anak penderita talasemia mayor di kota Bandung. Sosio Informa 2011;16:157-76.

5. Hastuti RP. Analisis Faktor yang berhubungan dengan tingkat kecemasan orang tua anak talasemia di RSUD Ahmad Yani Metro. Jurnal Kesehatan Metro Sai Wawai 2016;8:49-54.

6. Aji DN, Silman C, Aryudi C, dkk. Faktor-faktor yang berhubungan dengan kualitas hidup pasien thalassemia mayor di Pusat Thalassemia Departemen Ilmu Kesehatan Anak RSCM. Sari Pediatri 2009;11:85-9.

7. Nasiri M, Hosseini H, Shahmohammadi S. Mental health status in patients with thalassemia major in Iran. J Pediatr Rev 2014;2:55-61.

8. Tawarina I. Gambaran emosi dan perilaku pada anak talasemia di ruang thursina 1 Rumah Sakit Umum Daerah Dr. Zainoel Abidin Banda Aceh. Etd Unsyiah; 2018.

9. Fadlyana E, Ma'ani F, Elizabeth M, Reniarti L. Correlation between serum ferritin level and growth disorders in children with thalassemia. Am J Clin Med Res 2017;5:31-5.

10. Shang $\mathrm{X}, \mathrm{Xu} \mathrm{X}$. Update in the genetics of thalassemia: what clinicians need to know. Best Pract \& Res Clin Obstet Gynaecol 2017;39:3-15.

11. Batubara JR. Adolescent development (perkembangan remaja). Sari Pediatri 2010;12:21-9.

12. Mubasyiroh R, Suryaputri IY, Tjandrarini DH. Determinan gejala mental emosional pelajar SMP-SMA di Indonesia tahun 2015. Indones Bull Health Res 2017;45:103-12.

13. Behdani F, Badiee Z, Hebrani P, dkk. Psychological aspects in children and adolescents with major thalassemia: a case-control study. Iranian J Pediatr 2015;25:1-8.

14. Venty V, Rismarini R, Puspitasari D, Kesuma Y, Indra RM. Depression in children with thalassemia major: prevalence and contributing factors. Paediatrica Indones 2018;58:263-8.

15. Yengil E, Acipayam C, Kokacya MH, dkk. Anxiety, depression and quality of life in patients with beta thalassemia major and their caregivers. Int J Clin Exp Med 2014;7:2165.

15. Riyana M, Riza M. Penilaian Gangguan Perilaku Anak Talasemia Mayor dengan Menggunakan The Child Behavior Checklist. Sari Pediatri 2018;19:127-30.

17. Maghfiroh R, Okatiranti O, Sitorus RE. Gambaran harga diri pasien talasemia remaja (usia 14-21 tahun) di Klinik Hemato-Onkologi RSUP Dr. Hasan Sadikin Bandung. Jurnal Keperawatan BSI 2014;2:130-37. 